\title{
A method for the destruction and analysis of biogenic silicon in two Antarctic diatom species: Thalassiosira sp. and Chaetoceros brevis
}

\author{
A. C. Fischer • O. M. Steinebach • K. R. Timmermans • H. T. Wolterbeek
}

Received: 16 February 2006 / Revised and Accepted: 28 June 2006 / Published online: 10 November 2006

(C) Springer Science + Business Media B.V. 2006

\begin{abstract}
Diatoms in the Southern Ocean are limited by iron and light, and therefore produce little biomass. Sufficient biomass for analysis under these conditions requires large sample volumes, and diatom samples are therefore often pre-concentrated on a filter. A method for the digestion of diatom cells on polycarbonate filters, that is also suitable for trace metal analysis, is described here. Additional analysis by inductively coupled plasma-optical emission spectroscopy (ICPOES) is used for the determination of biogenic silicon. Although several procedures were tested, the method of Hauptkorn et al., which uses tetramethylammonium hydroxide for the destruction of silicon is adapted here [Hauptkorn et al. (2001) Fres J Anal Chem 370:246250]. Additional nitric acid is added to destroy the polycarbonate filters. The described method results in clear digests and a good correlation between cell numbers and silicon content. Using this procedure,
\end{abstract}

A. C. Fischer $(\bowtie) \cdot$ O. M. Steinebach $\cdot$ H. T. Wolterbeek Faculty of Applied Sciences, Department of Radiation, Radionuclides and Reactors, Delft University of Technology, Mekelweg 15, 2629 JB Delft, The Netherlands

e-mail: science@astrid.thatsme.nl

K. R. Timmermans

Department of Marine Chemistry and Geology,

Royal Netherlands Institute for Sea Research (NIOZ),

P.O. Box 59, 1790 AB Den Burg, Texel, The Netherlands the cellular silicon content for Chaetoceros brevis was determined as $86 \pm 4 \mathrm{fmol}^{\text {cell }^{-1}}$. For Thalassiosira sp. a sensitivity effect was observed, and silicon content was determined as $\mathrm{Si}=4.2 \times 10^{-7}\left(1-\exp ^{-2.2 \times 10^{-7} \text { cells }}\right)$. The obtained cellular silicon contents are in good agreement with values presented in the literature.

Key words Chaetoceros brevis - digestion · inductively coupled plasma-optical emission spectroscopy $\cdot$ seawater - silicon - Thalassiosira sp.

\begin{tabular}{|c|c|}
\hline Abbrevia & \\
\hline HNLC & High-nutrient low-chlorophyll \\
\hline ICP-OES & $\begin{array}{l}\text { Inductively coupled plasma-optical } \\
\text { emission spectroscopy }\end{array}$ \\
\hline INAA & Instrumental neutron activation analysis \\
\hline ICP-MS & $\begin{array}{l}\text { Inductively coupled plasma-mass spec- } \\
\text { troscopy }\end{array}$ \\
\hline TM & Tetramethylammonium hydroxide \\
\hline
\end{tabular}

\section{Introduction}

Phytoplankton are at the base of the food chain and are responsible for $\mathrm{CO}_{2}$ fixation in the oceans (Bakker et al. 2001; Boyd et al. 2000). In the Southern Ocean, diatoms are limited in their growth by iron and light (Bowie et al. 2001; De Baar et al. 
1999; De Baar and De Jong 2001; Martin et al. 1994) and therefore have low biomass. For many studies it is necessary to know the number of diatom cells per sample. The most straightforward technique to use is cell counting, using either settling chambers and subsequent microscopic counting by haemocytometer or a flowcytometer.

However, in high-nutrient low-chlorophyll (HNLC) regions there are restrictions in the sampling methods: due to low biomass, even large volumes will yield only low concentrations of cells. This necessitates preconcentration, e.g., via filtration, before the number of cells can be estimated using biomarkers. Several biomarkers, such as chlorophyll, carbon, phosphorus, nitrogen and silicon, can be used (Landry et al. 2000; Timmermans et al. 2004). Further sample analysis requires acid or alkaline (microwave) destruction with sufficient digest volume, which will limit detection of these markers and can make accurate analysis problematic when biomass is very low.

In this paper we test the validity of a digestion method that can be used in trace metal analysis and measured the biogenic silicon content of two Antarctic diatoms. The main considerations for choosing silicon were:

1. Diatoms have a cell wall that is made of amorphous hydrated silicon. When the diatom cell wall is fully formed, it consists of multiple siliceous components (Taylor 1980); thus, the silicon content is relatively high.

2. Chlorophyll could not be used because it is a biodegradable substance (Rontani and Volkman 2003) that can also vary with the concentration of available iron (Hutchins and Bruland 1998; Takeda 1998).

3. Carbon content could not be measured as the cells were separated from the culture medium by filtering over polycarbonate filters. As many studies in the Southern Ocean also focus on metal limitation (Bowie et al. 2002; Boyd et al. 2000; De Baar et al. 1999; Martin et al. 1991, 1994), this type of filter was chosen because of its low affinity for metal adsorption (Weltje et al. 2003).

4. Due to the low biomass, intracellular phosphorus and nitrogen levels would be lower than the detection limit, especially in a seawater environment where high salt concentrations can affect the analysis.
For digestion of the samples, the opal diatom valve needs to be completely dissolved, as well as the filters that were used for pre-concentration. Although some controversy exists over cellular silicon content under iron stress (Boyle 1998; Hutchins and Bruland 1998; Takeda 1998), silicon is one of the major nutrients for diatoms and therefore a good candidate with which to test our method.

Silicon was determined by inductively coupled plasma-optical emission spectroscopy (ICP-OES), as this technique gives a very sensitive qualitative and quantitative measurement, whereas in other techniques silicon can cause interference. For example: ICP-mass spectroscopy (ICP-MS) causes interference on the silicon isotope, and instrumental neutron activation analysis (INAA) cannot distinguish between aluminium and silicon. However, this does limit the choice of destruction method: hydrogen fluoride cannot be used as it etches glass and quartz and will give rise to high silicon noise levels; high sodium content will result in matrix effects in the ICP-OES analysis.

In an ongoing study investigating the effect of UVlight on iron uptake by diatoms (Rijkenberg 2005), biomass was separated from the medium using $0.2 \mu \mathrm{m}$ polycarbonate filters for subsequent trace metal analysis. In this study we established a tracemetal clean method for the digestion of two Antarctic diatoms, and used ICP-OES for silicon measurements. Specifically, we investigated the silicon content of the species Thalassiosira sp. and Chaetoceros brevis, representing large $(\sim 70 \mu \mathrm{m}$ diameter $)$ and small $(\sim 5 \mu \mathrm{m}$ diameter) diatom species, respectively.

\section{Materials and methods}

Reagents and standard solutions

All reagents used were of analytical grade, unless stated otherwise. $\mathrm{HNO}_{3}$ Suprapur $65 \%$ (v/v) obtained from Merck (Darmstadt, Germany) was used in all ICP-OES experiments. The silicon ICP standard solution (CertiPUR, $1,000 \mathrm{mg} \mathrm{L}^{-1} \mathrm{SiO}_{2}$ in $2 \% \mathrm{NaOH}$ ) was obtained from Merck. Tetramethylammonium hydroxide (TMAH), 25\% w/v, was obtained from Sigma (St. Louis, MO). Distilled water was prepared using Waters Elix 5 System distillation equipment (resistivity $>5 \Omega \mathrm{cm}$; conductivity $<0.2 \mu \mathrm{S} \mathrm{cm}^{-1}$ ). 
Subsequently, ultra pure MilliQ water (resistivity $18 \mathrm{M} \Omega$ ) was prepared with a Waters Milli-Q Academic A10 water purification system (Waters Millipore, Milford, MA). All ICP-OES results given in this work were calculated using the calibration with the standard solutions mentioned above.

For the TiEDTA/citrate wash (Hudson and Morel 1989), filtered $(0.2 \mu \mathrm{m})$ seawater sampled at $51^{\circ} \mathrm{S}$ $20^{\circ} \mathrm{E}$ (1 November 2000) in the Southern Ocean during the EISENEX cruise was used. A torpedo was towed approximately $5 \mathrm{~m}$ alongside the ship (R.V. Polarstern, ANT XVIII/2) with acid-washed braided PVC tubing attached to it. Using a Teflon diaphragm pump driven by a compressor, the seawater was pumped into an over-pressurised class 100 clean air container. The seawater was filtered in-line with a cutoff of $0.2 \mu \mathrm{m}$ (Sartorius Sartobran filter capsule 5231307H8). This seawater contained $0.32 \mathrm{nM}$ dissolved $\mathrm{Fe}$ and $1.69 \pm 0.19 \mathrm{nM}$ naturally occurring ligands with a conditional stability constant $\left(\log \mathrm{K}^{\prime}\right)$ of $21.43 \pm 0.24$ (errors given represent the 95\% confidence interval; see chapter 6, Rijkenberg 2005). Nutrient concentrations: $26 \mu \mathrm{M} \mathrm{NO}_{3}^{-}, 24.45 \mu \mathrm{M} \mathrm{Si}$, $1.82 \mu \mathrm{M}$ P (M. Rijkenberg, personal communication). The TiEDTA reagent was prepared as described by Hudson and Morel (1989). The digestion reagents used were: $\mathrm{NaOH}$ (Baker), 37\% $\mathrm{HCl}$ solution (Baker), $25 \%(w / v)$ TMAH (Sigma) and 65\% (v/v) Suprapur $\mathrm{HNO}_{3}$ solution (Merck). For standard additions, purchased $\mathrm{Na}_{2} \mathrm{SiO}_{3}$ (Sigma) was used.

\section{Diatoms}

Cultures of Thalassiosira sp. and Chaetoceros brevis (originating from the Royal NIOZ culture collection, K.R. Timmermans) were used for these experiments. C. brevis is a small diatom, 4-6 $4 \mathrm{~m}$, with a maximal growth rate of $0.39 \mathrm{day}^{-1}$, growing as single cells (Timmermans et al. 2001). Thalassiosira sp. is a large $(70 \mu \mathrm{m})$, chain-forming diatom, with a maximal growth rate of 0.31 day $^{-1}$ (Timmermans et al. 2004). C. brevis and Thalassiosira sp. cells were precultivated in the same Southern Ocean seawater (see above) at the same temperature $\left(4^{\circ} \mathrm{C}\right)$ and day/night cycle (16 h: $8 \mathrm{~h}$, respectively, with a light intensity of $80 \mu \mathrm{mol}$ photons $\mathrm{m}^{2} \mathrm{~s}^{-1}$ ) as used during the experiments, but with the addition of $5 \mathrm{nmol} \mathrm{L}{ }^{-1} \mathrm{Fe}$, in order to generate sufficient biomass for the experiments.
Samples

For sterile and contamination-free conditions, all experiments were carried out in a laminar flow-bench. Before filtration, the number of cells per millilitre was determined by settling the algal cells and subsequent haemocytometer counting. To test the effectiveness of the digestion procedure, a concentration range of cells was chosen to investigate whether a linear relationship between number of cells and the silicon content could be obtained. For Thalassiosira sp. this range was chosen between 250 and 13,500 cells whereas for C. brevis a range of $1.0 \times 10^{5}-6.7 \times 10^{6}$ cells was used. The chosen amount of cells was filtered on an acid-cleaned and MilliQ-water-rinsed $0.2 \mu \mathrm{m}$ polycarbonate filter (Millipore) in a Swinnix filter holder (Millipore). Future experiments will focus on iron uptake, and cells will have to undergo a TiEDTA/ citrate wash (Hudson and Morel 1989) for removal of extracellular iron. For comparison, this protocol is copied here. This washing step does not alter the cells (Veldhuis, personal communication). After the TiEDTA/citrate wash, filters are removed from their holder and placed in a $15 \mathrm{~mL}$ polypropylene centrifuge tube. The filters are dried in a laminar flow bench overnight. After digestion, the samples $(10 \mathrm{~mL}$ each) are analysed by ICP-OES.

\section{Apparatus}

Silicon concentrations in algae were determined by a Perkin-Elmer 4300 Dual View ICP-OES spectrometer equipped with a Perkin Elmer As-93Plus Autosampler (Perkin-Elmer, Boston, MA). Total silicon concentrations were measured under the operating conditions and specific wavelengths given in Table 1. The emission spectrum lines for silicon are given in Table 2. External calibrations were used for each $\mathrm{Si}$ wavelength: no matrix effects were observed in the determined calibration lines.

\section{Results and discussion}

In our experiments, cells are separated from the growth medium (Southern Ocean seawater, $\mathrm{pH}=8$ ) by filtering onto polycarbonate filters. For ICP-OES analysis of the biogenic silicon content of the two diatoms, both the filters and the cells need to be dissolved completely. 
Table 1 Instrumental operating conditions: inductively coupled plasma-optical emission spectroscopy (ICP-OES)

\begin{tabular}{ll}
\hline $\begin{array}{l}\text { RF coil with quartz } \\
\text { bonnet: RF Power }\end{array}$ & $1,300 \mathrm{~W}$ \\
Torch injector & Ceramic (alumina) \\
Cooling gas (Ar) flow rate & $15 \mathrm{~L} \mathrm{~min}^{-1}$ \\
Nebulizer spray chamber & Ryton Cross-Flow II \\
Nebulizer gas & Argon \\
Gas pressure & $108.0 \mathrm{kPa}$ \\
Gas flow rate & $0.80 \mathrm{~L} \mathrm{~min}^{-1}$ \\
Torch view & Axial and radial \\
Sample uptake rate & $1.50 \mathrm{~mL} \mathrm{~min}^{-1}$ \\
Sample flush & $45 \mathrm{~s}$ \\
Integration time & Auto, minimum $5 \mathrm{~s}$, \\
& maximum $50 \mathrm{~s}$ \\
Resolution & Normal \\
Spectral profiling & No \\
Replicates & 5 \\
Background & 3 -point \\
Integration time & $5 \times 5 \mathrm{~s}$ \\
\hline
\end{tabular}

The problem that arises here is that the filter material (polycarbonate) is preferably dissolved in acid, and that the silicon valve of the diatoms is best digested under alkaline conditions. Also, both acid and alkaline digestion usually involves high salt concentrations, which can interfere with the intended ICP-OES measurement. Initial experiments were carried out at different $\mathrm{NaOH}$ concentrations, varying from 0.5 to $10 \mathrm{M}$. At elevated temperatures $\left(60^{\circ} \mathrm{C}\right)$ and high $\mathrm{NaOH}$ concentrations $(5-10 \mathrm{M})$ the samples would eventually dissolve, but the high sodium concentrations made analysis by ICP-OES impossible due to matrix effects.

The procedure described by Hauptkorn et al. (2001) was also tested. Their method involves the use of TMAH in combination with microwaveassisted autoclave digestion. However, when this method was applied to our samples, a brownish residue was observed, suggesting decomposition of the sample. The samples could also not be dissolved afterwards, either with MilliQ-water, or in acid or alkaline solutions.

Despite this, TMAH looked promising, because it would create an alkaline environment without sodium interference, and it is also used in other silicon determination methods ( $\mathrm{Yu}$ et al. 2003). Therefore, we adapted the method described by Hauptkorn et al. (2001). Samples were digested with $500 \mu \mathrm{L} \mathrm{TMAH} \mathrm{in}$ a polypropylene centrifugation tube at $65^{\circ} \mathrm{C}$ for $1 \mathrm{~h}$, after which the samples were diluted with $9.3 \mathrm{~mL}$
Milli-Q water. To make sure that the filters would also be dissolved, the samples were acidified with $200 \mu \mathrm{L}$ $65 \%(\mathrm{v} / \mathrm{v}) \mathrm{HNO}_{3}$. The samples were homogenised on a vortex mixer, and clear digests were obtained. In addition, microscopic inspection showed that cells were completely destroyed, although chloroplast fragments seemed unaffected (K.R. Timmermans, unpublished observation). The samples were kept refrigerated until further analysis. Silicon analysis by ICP-OES was performed using five different discrete wavelengths (see Table 2). A typical ICP-OES spectrum of silicon showing the selected wavelengths with the highest intensity is shown in Figure 1.

To test the possibility of interference from the algae-seawater matrix in our digestion method, a standard addition of $1 \mu \mathrm{mol}$ silicon as $\mathrm{Na}_{2} \mathrm{SiO}_{3}$ in Milli-Q water was added to four samples containing blank filters and to four samples containing 50,000 cells of $C$. brevis. The results indicate that the digestion is reproducible and has only a small matrix effect (Figure 2). The observed matrix effect of $78.7 \%$ is likely to be caused by the presence of residues from seawater salts. Therefore a correction factor needs to be applied to the results:

Correction factor for matrix effects $=\frac{100 \%}{78.7 \%}=1.27$

As a second test we determined the biogenic silicon content of two diatoms: Thalassiosira $\mathrm{sp}$. and C. brevis. There is, however, growing evidence that diatoms

Table 2 Emission wavelengths for ICP-OES (axial and radial view)

\begin{tabular}{|c|c|c|c|c|}
\hline Analyte & $\begin{array}{l}\text { Spectral } \\
\text { line }[\mathrm{nm}]\end{array}$ & $\begin{array}{l}\text { Range of } \\
\text { concentra- } \\
\text { tions } \\
{\left[\mathrm{mg} \times 10^{-4}\right]^{a}}\end{array}$ & $\begin{array}{l}\text { Detection } \\
\text { limit } \\
{\left[\mathrm{mg} \times 10^{-5}\right]}\end{array}$ & $\begin{array}{l}\text { Detection limit } \\
\text { of cells } C \text {. } \\
\text { brevis/ } \\
\text { Thalassiosira } \\
\text { sp. }\end{array}$ \\
\hline \multirow[t]{5}{*}{$\mathrm{Si}$} & 251.611 & $5-10$ & 1.2 & $\begin{array}{r}6.3 \times 10^{-4} / \\
1.3 \times 10^{-2}\end{array}$ \\
\hline & 212.412 & $5-10$ & 1.6 & $\begin{array}{r}8.4 \times 10^{-4} / \\
1.7 \times 10^{-2}\end{array}$ \\
\hline & 288.158 & $5-10$ & 2.7 & $\begin{array}{r}1.4 \times 10^{-5} / \\
2.9 \times 10^{-2}\end{array}$ \\
\hline & 252.851 & $5-10$ & 3.1 & $\begin{array}{c}1.6 \times 10^{-5} / \\
3.3 \times 10^{-2}\end{array}$ \\
\hline & 221.667 & $5-10$ & 4.1 & $\begin{array}{r}2.1 \times 10^{-5} / \\
4.4 \times 10^{-2}\end{array}$ \\
\hline
\end{tabular}

${ }^{a}$ Calibration equations: linear through 0 for all elements 
Figure 1 Inductively coupled plasma-optical emission spectroscopy (ICP-OES) silicon spectrum $(170-440 \mathrm{~nm})$ at a silicon concentration of $0.5 \mathrm{mg}$ $\mathrm{L}^{-1}$. The intensity (arbitrary units) is plotted versus the wavelength in nanometres.

\section{Silicon spectrum}

$[\mathrm{Si}]=0.5 \mathrm{mg} \mathrm{L}^{-1}$

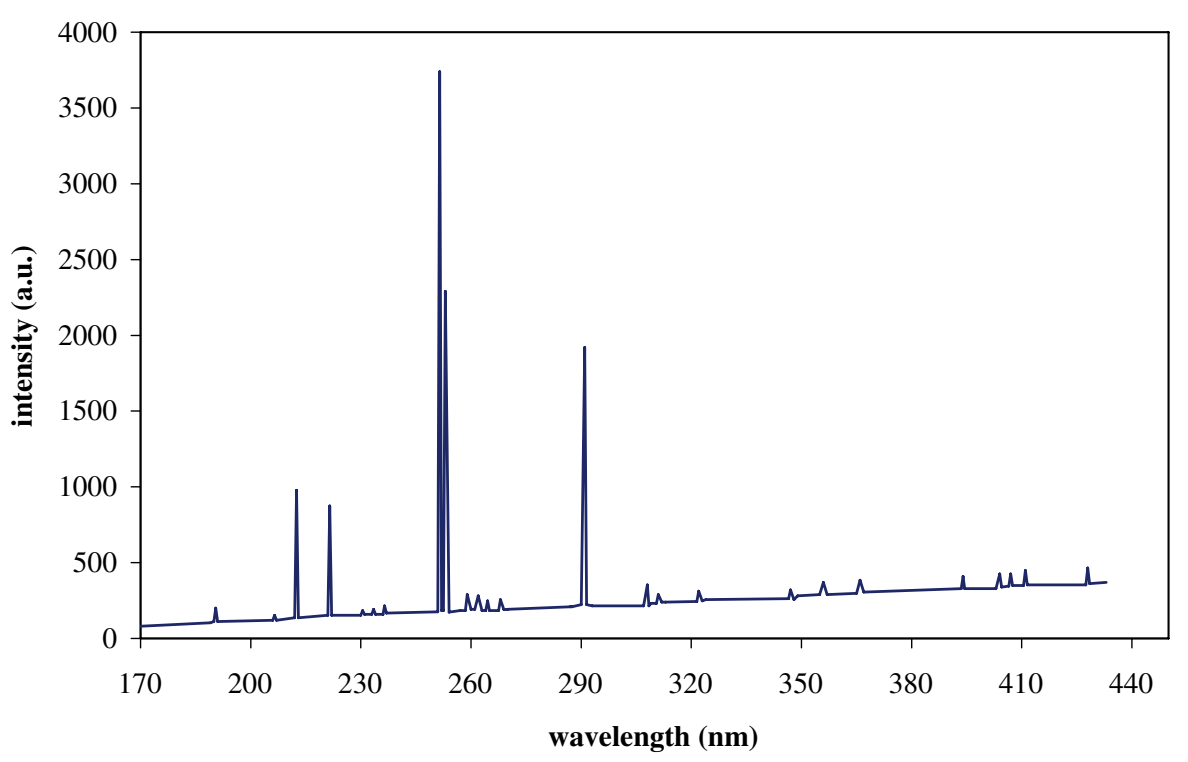

in HNLC regions may have elevated $\mathrm{Si}$ :C ratios compared to nutrient-replete diatoms (Hutchins and Bruland 1998; Takeda 1998). These higher ratios might be the result of low Fe availability (Brzezinski et al. 2001; Hutchins et al. 2002; Martin et al. 1991). Iron limitation may lead to more silicified diatom biomass (Hutchins and Bruland 1998), and iron enrichment experiments may cause the formation of less silicified diatoms (Boyle 1998). However, experiments where iron limitation leads to lower silicon content of diatoms have also been reported (De La Rocha et al. 2000).

A range of cell densities for $C$. brevis and Thalassiosira sp. were digested with the described procedure and their biogenic silicon content measured. The ICP-OES detection limits for these two species are given in Table 2. There was a good correlation between the number of cells and the silicon content for $C$. brevis, with the silicon content being determined as $86 \pm 4 \mathrm{fmol} \mathrm{cell}^{-1}$ (Figure 3). For
Figure 2 Recovery (\%) after destruction of a $1 \mu \mathrm{mol} \mathrm{Si}$ addition to blank filters (numbers 1-4) and filters containing Chaetoceros brevis (numbers 5-8, background signal of C. brevis is subtracted).

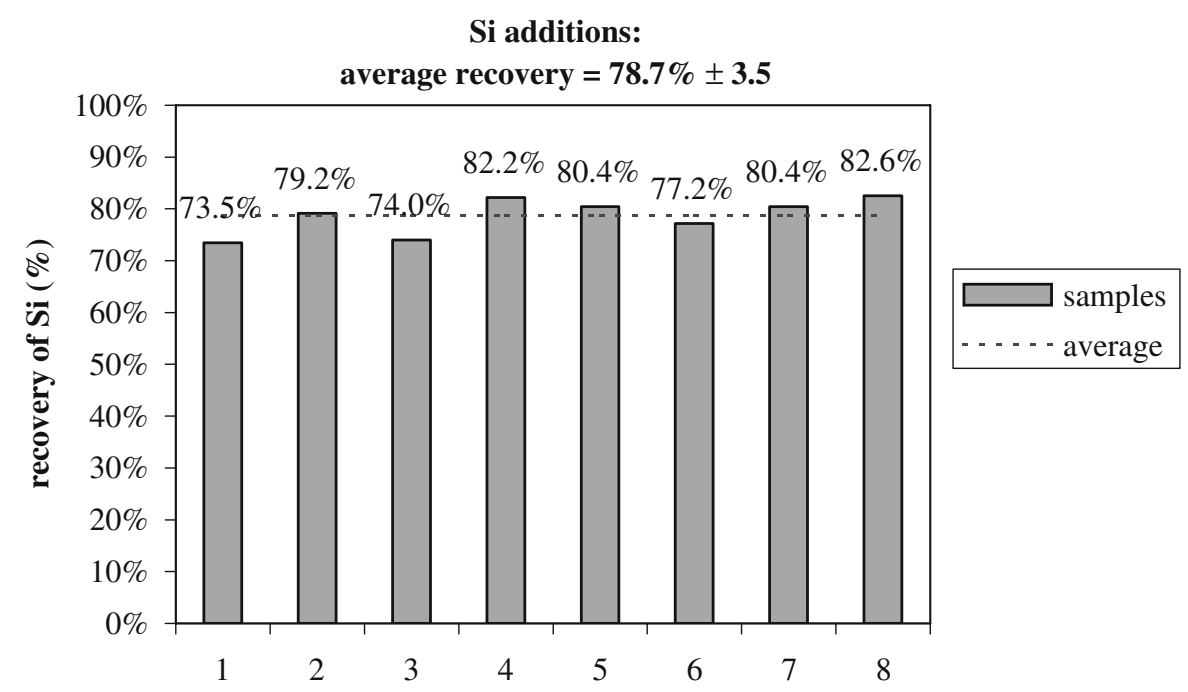


Figure 3 Silicon content (mol) versus number of cells for Chaetoceros brevis as measured by ICP-OES; cellular silicon content determined as $86 \mathrm{fmol} \mathrm{cell}^{-1}$.

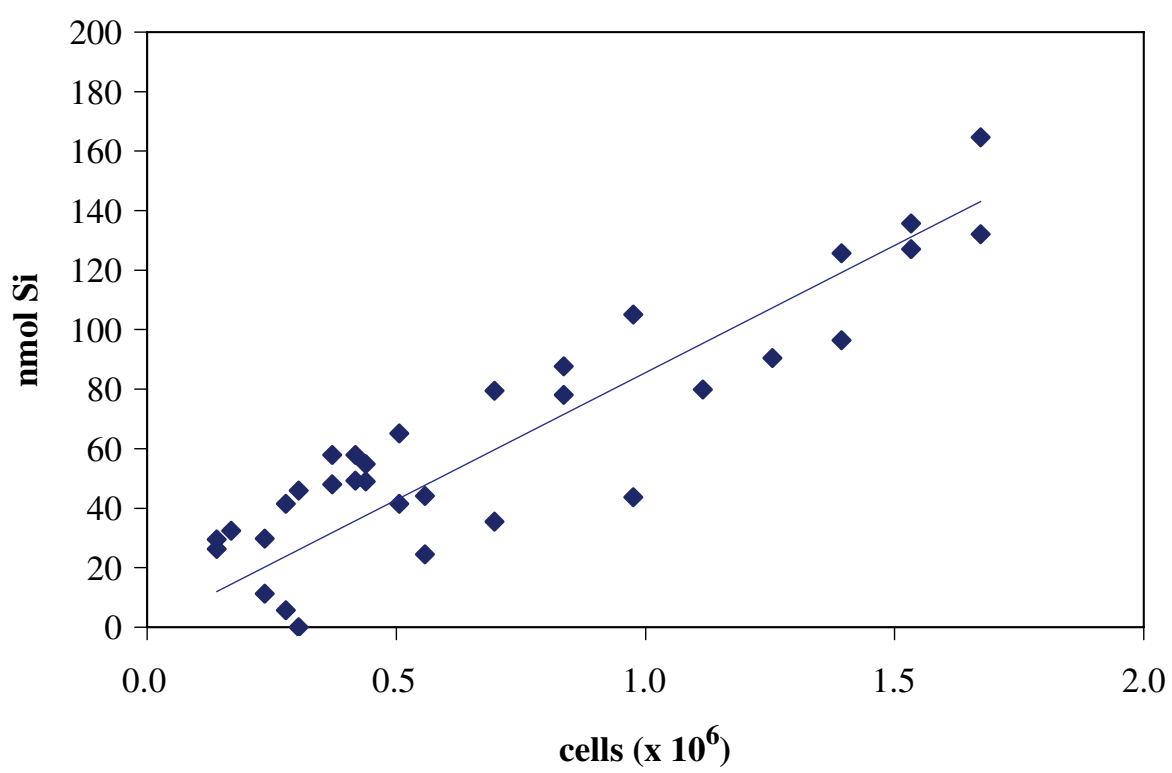

Thalassiosira sp. (Figure 4) a sensitivity effect was observed: at low concentrations the calibration seemed more sensitive towards silicon than at higher concentrations. This may be due to the fact that, at higher concentrations, the dissolved cell contents interfere with the ICP-OES measurement. Another possibility for the lower silicon content at higher cell concentrations is the varying silicate content during asexual reproduction (Round et al. 1990). The biogenic silicon content for Thalassiosira sp. (Figure 4) was determined as $S i=4.2 \times 10^{-7}\left(1-\exp ^{-2.2 \times 10^{-7} \text { cells }}\right)$.

The values observed for cellular silicon content for C. brevis and Thalassiosira sp. are in the same range as those observed for similar diatom species (Hutchins and Bruland 1998; Paasche 1980; Takeda 1998). We therefore conclude that our digestion method is effec-
Figure 4 Silicon content (mol) versus number of cells for Thalassiosira sp. as measured by ICP-OES: sensitivity of the measurement changes for cell concentrations higher than 1,400 cells: silicon content determined as $S i=4.2 \times 10^{-7}$ $\left(1-\exp ^{-2.2 \times 10^{-7} \text { cells }}\right)$.

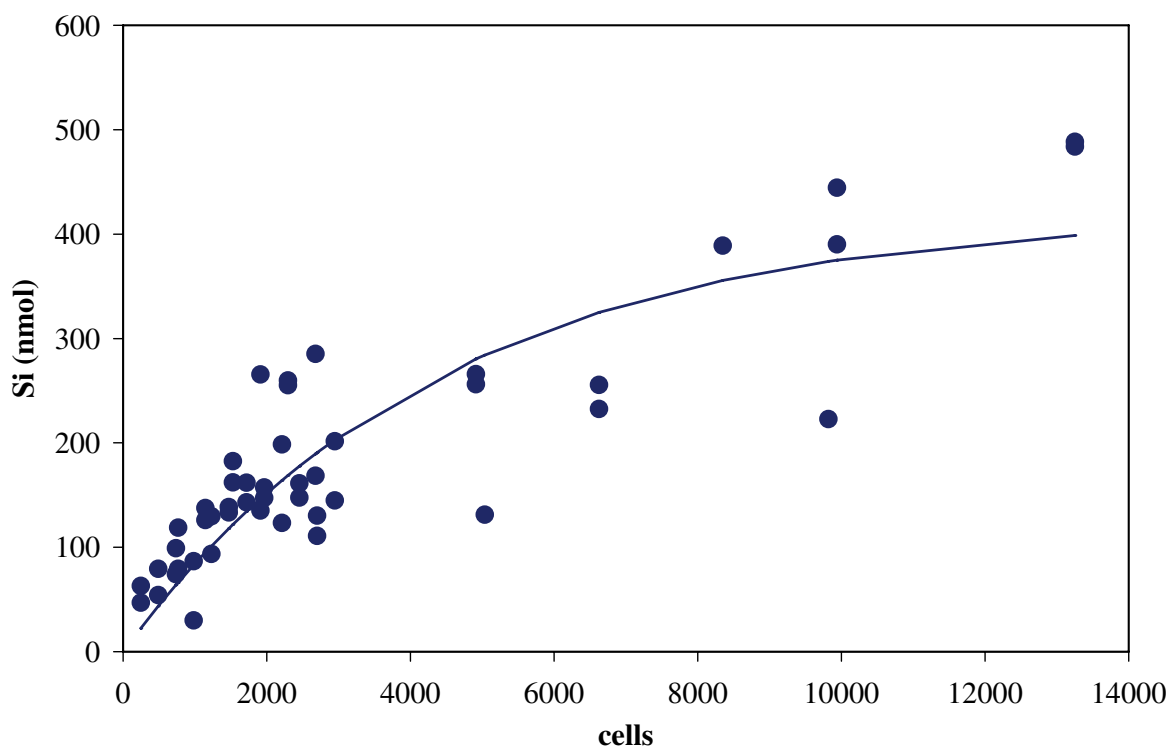


tive, and can be used for the estimation of biogenic silicon content.

Acknowledgements The authors would like to thank Micha Rijkenberg (Royal NIOZ, The Netherlands), Koos Kroon, Tona Verburg and Heleen Brasser (Delft University of Technology) for their help with these experiments. The Netherlands Society for Scientific Research (NWO) funded this research, via the Netherlands AntArctic Programme (NAAP, grant 85120004).

\section{References}

Bakker DCE, Watson AJ, Law CS (2001) Southern Ocean iron enrichment promotes inorganic carbon drawdown. DeepSea Res II 48:2483-2507

Bowie AR, Maldonado MT, Frew RD et al (2001) The fate of added iron during a mesoscale fertilisation experiment in the Southern Ocean. Deep-Sea Res II 48:2703-2743

Bowie AR, Whitworth DJ, Achterberg EP et al (2002) Biogeochemistry of $\mathrm{Fe}$ and other trace elements $(\mathrm{Al}, \mathrm{Co}, \mathrm{Ni})$ in the upper Atlantic Ocean. Deep-Sea Res I 49:605-636

Boyd PW, Watson AJ, Law CS et al (2000) A mesoscale phytoplankton bloom in the polar Southern Ocean stimulated by iron fertilization. Nature 407:695-702

Boyle E (1998) Oceanography-pumping iron makes thinner diatoms. Nature 393:733-734

Brzezinski MA, Nelson DM, Franck VM et al (2001) Silicon dynamics within an intense open-ocean diatom bloom in the pacific sector of the Southern Ocean. Deep-Sea Res II 48:3997-4018

De Baar HJW, De Jong JTM (2001) Distributions, sources and sinks of iron in seawater. In: Turner DR, Hunter KA (eds) The biogeochemistry of iron in seawater. Wiley, pp 123-254

De Baar HJW, De Jong JTM, Nolting RF et al (1999) Low dissolved $\mathrm{Fe}$ and the absence of diatom blooms in remote pacific waters of the Southern Ocean. Mar Chem 66:1-34

De La Rocha CL, Hutchins DA, Brzezinski MA et al (2000) Effects of iron and zinc deficiency on elemental composition and silica production by diatoms. Mar Ecol-Prog Ser 195:71-79

Hauptkorn S, Pavel J, Seltner H (2001) Determination of silicon in biological samples by ICP-OES after nonoxidative decomposition under alkaline conditions. Fres J Anal Chem 370:246-250

Hudson RJM, Morel FMM (1989) Distinguishing between extracellular and intracellular iron in marine-phytoplankton. Limnol Ocean 34:1113-1120
Hutchins DA, Bruland KW (1998) Iron-limited diatom growth and $\mathrm{Si}$ : $\mathrm{N}$ uptake ratios in a coastal upwelling regime. Nature 393:561-564

Hutchins DA, Sedwick PN, DiTullio GR et al (2002) Control of phytoplankton growth by iron and silicic acid availability in the subantarctic Southern Ocean: Experimental results from the SAZ Project. J Geophys Res-Oceans 106: 31559-31572

Landry MR, Constantinou J, Latasa M et al (2000) Biological response to iron fertilization in the eastern equatorial Pacific (IronEx II). III. Dynamics of phytoplankton growth and microzooplankton grazing. Mar Ecol-Progr Ser 201:57-72

Martin JH, Coale KH, Johnson KS et al (1994) Testing the iron hypothesis in ecosystems of the equatorial pacific-ocean. Nature 371:123-129

Martin JH, Gordon RM, Fitzwater SE (1991) The case for iron. Limnol Ocean 36: 1793-1802

Paasche E (1980) Silicon content of five marine plankton diatom species measured with a rapid filter method. Limnol Ocean 25:474- 480

Rijkenberg MJA (2005) Photochemistry and organic complexation of iron interactions in the Southern Ocean. Dissertation, University of Groningen. Available online: http://irs.ub.rug.nl/ppn/275114597

Rontani J-F, Volkman JK (2003) Phytol degradation products as biogeochemical tracers in aquatic environments. Org Chem 34: $1-35$

Round FE, Crawford RM, Mann DG (1990) Biology of diatoms. The diatoms. Biology and morphology of the genera. Cambridge University Press, Cambridge, pp 1-130

Takeda S (1998) Influence of iron availability on nutrient consumption ratio of diatoms in oceanic waters. Nature 393:774-777

Taylor FJR (1980) Basic biological features of phytoplankton cells. In: Morris I (ed) The physiological ecology of phytoplankton. Blackwell, Berkeley, CA, pp 3-55

Timmermans KR, Davey MS, Van der Wagt B et al (2001) Colimitation by iron and light of Chaetoceros brevis, $C$. dichaeta and C. calcitrans (Bacillariophyceae). Mar EcolProg Ser 217:287-297

Timmermans KR, Van der Wagt B, De Baar HJW (2004) Growth rates, half-saturation constants, and silicate, nitrate, and phosphate depletion in relation to iron availability of four large, open-ocean diatoms from the Southern Ocean. Limnol Ocean 49:2141-2152

Weltje L, den Hollander W, Wolterbeek HT (2003) Adsorption of metals to membrane filters in view of their speciation in nutrient solution. Environ Tox Chem 22:265-271

Yu LL, Fassett JD, Lindstrom AP (2003) Determination of Si in standard reference material SRM 295x Silica-on-Filter. J Anal Atom Spec 18:738-741 